\title{
Follicle rupture during ovulation with an emphasis on recent progress in fish models
}

\author{
Takayuki Takahashi, Akane Hagiwara and Katsueki Ogiwara \\ Laboratory of Reproductive and Developmental Biology, Faculty of Science, Hokkaido University, Sapporo, Japan \\ Correspondence should be addressed to T Takahashi; Email: ttakaha@sci.hokudai.ac.jp
}

\begin{abstract}
Ovulation, which is induced by the ovulatory luteinizing hormone (LH) surge, is a dynamic process that results in a discharge of one or more fertilizable oocytes from the ovarian follicle into the ovarian cavity or into the abdominal cavity. Follicle rupture is a core event of the ovulatory process and has been the subject of intensive investigation. Many studies have been performed in various vertebrate animals that focused on proteolysis during ovulation. Despite much effort, the proteases responsible for follicle rupture in ovulation have not yet been identified for mammalian species. However, studies conducted using the teleost medaka have recently provided valuable information about the follicle rupture process. Follicle rupture during medaka ovulation is accomplished by a two-step extracellular matrix (ECM) hydrolysis mechanism involving two distinct protease systems, the urokinase-type plasminogen activator-1 /plasmin and the matrix metalloproteinase system. In the 24-h spawning cycle of the fish, the former protease system is activated first, and the latter subsequently becomes active. Proteolytic activities of these systems are regulated by their intrinsic inhibitors. The endocrine regulation of the rupture was examined by investigating the expression of matrix metalloproteinase 15 (Mmp15), which is the only LH-inducible protease among those involved in the rupture process. At least two transcription factors, classical nuclear progestin receptor and CCAAT/enhancer-binding protein $\beta$, play critical roles in the expression of the protease transcript. This review also summarizes studies addressing follicle rupture during ovulation conducted using other teleost models to understand the current status of teleost ovulation studies.

Reproduction (2019) 157 R1-R13
\end{abstract}

\section{Introduction}

In most sexually reproducing animals, including both invertebrates and vertebrates, oocytes generally develop in the ovarian follicle. After the oocytes become fully developed, they escape from the follicle. This process is called ovulation and is induced by the surge of luteinizing hormone (LH). The gonadotropin surge initiates the ovulatory process by programing the transcriptional profiles of many genes in the follicle (Espey \& Richards 2002, Richards 2007, Gilbert et al. 2011, Christenson et al. 2013, Richards et al. 2015, Lussier et al. 2017), causing multiple biochemical and biophysical changes.

Follicle rupture during ovulation has attracted the most attention among researchers. Many studies have been conducted (mainly using mammalian species) to understand this process. These have included the search for proteolytic enzymes critically involved in follicle rupture, the determination of the molecular mechanism by which the rupture is accomplished, and the regulation of expression of the enzymes in the follicle. Unfortunately, the proteolytic enzymes responsible for the rupture have not been identified in mammals. For more information on the research addressing the role of proteases in follicle rupture during ovulation in mammalian species, readers are referred to the previously published reviews (Ny et al. 2002, Smith et al. 2002, Ohnishi et al. 2005, Curry \& Smith 2006, Espey \& Richards 2006, Liu et al. 2013).

Teleosts belong to the class Osteichthyes (bony fishes), which represent the largest vertebrate class and a very diverse animal group. They are predominantly dioecious and have extracorporeal spawning. In some teleost species, hermaphroditism and gynogenesis occur (Nagahama 1983). In teleosts, studies focused on the implication of proteases and the protease inhibitors have been performed using various species (Berndtson \& Goetz 1988, 1990, Ogiwara et al. 2005, Bobe et al. 2006, Crespo et al. 2010, 2013, 2015, Liu et al. 2017). These studies have strengthened the notion that proteolytic events are necessary for successful ovulation in teleosts as well. At present, our understanding of this issue is most advanced in medaka (Oryzias latipes), a freshwater teleost. There are many advantages to using the medaka fish for the studies: (i) It spawns every day under suitable light and temperature conditions. (ii) The timing of the sequential processes of spawning, such as the completion of vitellogenesis, the gonadotropin LH surge, the synthesis of the critical steroid $17 \alpha, 20 \beta$ dihydroxy-4-pregnen-3-one $(17,20 \beta \mathrm{P})$ that initiates final 
oocyte maturation and ovulation, breakdown of the germinal vesicle and ovulation, can be determined. (iii) An experimental system for studying ovulation using dissecting follicles in vitro has been established. Hence, the medaka affords a tractable model system for the study of ovulation.

To our knowledge, there are few reports in the literature that reviewed ovulation with an emphasis on the role of proteolytic enzymes in teleost ovulation. In this review, we have described the findings gained from the medaka experimental model because studies using this species have provided comprehensive knowledge of teleost ovulation. Throughout the review, we also mention the relevant findings obtained from experiments using other teleosts as well as mammals to help understand the current status of teleost ovulation studies.

The literature search was performed using the electronic database PubMed until August 2018 to identify original articles.

\section{Ovary and follicle structure of teleosts}

Reproduction in vertebrates is generally thought to be controlled by the hypothalamic-pituitary-gonadal (HPG) axis, and the precise actions of main hormones and factors involved in the system have been the subject of intensive research. GnRH is widely known to be a master player in the control of reproduction by stimulating synthesis and release of gonadotropins, follicle-stimulating hormone ( $\mathrm{FSH})$ and $\mathrm{LH}$, in the pituitary gland. Hence, follicle structure and its function are under the control of the HPG axis.

In general, the ovaries of teleosts are a paired organ. In some species, including medaka, paired structures become fused into a single organ in their early developmental stages. The ovary consists of oogonia, oocytes, somatic cells that surround the individual germ cell, stroma and vascular and nervous tissue (Nagahama 1983). Most teleosts reproduce in a cyclic manner, and the ovary exhibits considerable changes at different times during the reproductive cycle. Teleost fishes, such as medaka, goldfish and zebrafish, spawn many times during a prolonged breeding season. In these fish, oocytes at all stages of development are observed in the ovary (Wallace \& Selman 1981, Nagahama 1983).

Previous studies of teleost ovaries have revealed the detailed structure of ovarian follicles (Yamamoto 1963, Hirose 1972, Pendergrass \& Schroeder 1976, Grier 2000, Grier et al. 2007, 2009). The whole body of the ovary is covered by the ovarian germinal epithelium lined with a basement membrane. In the follicle that has completed folliculogenesis, the follicular envelope surrounding the large oocyte, that contains a globule of fluid yolk, consists of a granulosa cell layer, basement membrane, and a theca cell layer from inside to outside (Fig. 1). The theca cell layer of the teleosts has been reported to contain fibroblasts, collagen fibers, capillaries, and in
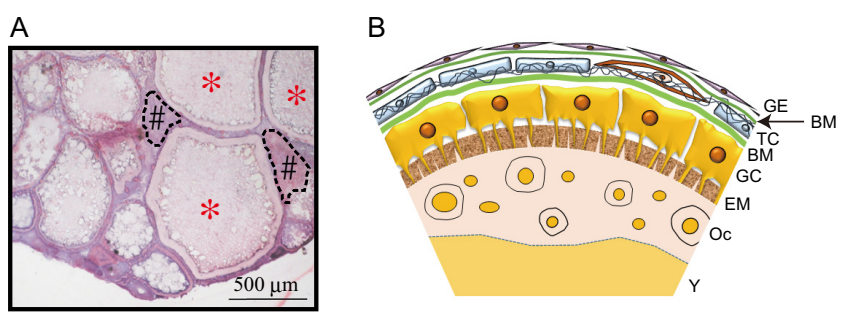

Figure 1 Ovary and follicle structure of sexually mature female medaka. (A) Frozen sections of the medaka fish ovary isolated $19 \mathrm{~h}$ before ovulation were stained with hematoxylin-eosin. Large follicles that are destined to ovulate at the next ovulation time are indicated by asterisks. The follicle tissue of the postovulatory follicle that had just ovulated is indicated by \#. (B) The follicle envelope of the preovulatory follicle that is destined to ovulate is schematically shown. BM, basement membrane; EM, egg membrane; GC, granulosa cell; GE, germinal epithelium; Oc, oocyte cytoplasm; TC, theca cell; Y, yolk.

some species, special thecal cells (Nagahama 1983). In some fishes, the follicles share the basement membrane with the surface germinal epithelial cells at the follicle attachment site (Grier et al. 2005, 2007, 2009). This area of contact is presumed to be the rupture site of the follicle at ovulation. It has also been reported that there is no thecal layer between the shared basement membrane and the germinal epithelial cell layer (Grier et al. 2009). From these observations with ovarian follicles of several teleost species, the novel assumption emerges that breakdown of the shared basement membrane, follicle cell layer and overlying germinal epithelium would be sufficient for the oocyte to be ovulated (Grier et al. 2009). However, we currently present a schematic model for the follicular envelope of the medaka as shown in Fig. 1. Neither special theca cells nor fibroblasts are shown in the theca cell layer because previous morphological studies have reported the lack of these cells in the ovulatory follicle of the fish (Iwasaki 1973, Pendergrass \& Schroeder 1976). This model shows that the follicle envelope of follicles destined for ovulation consists of a single layer of granulosa cells surrounding an oocyte, a single layer of theca cells and a basement membrane between the two somatic cell layers. The envelope is further covered with a single layer of surface germinal epithelial cells with its own supporting basement membrane. This drawing is consistent with the electron microscopic observation reported by Pendergrass \& Schroeder (1976); the micrograph showed the presence of the theca cell layer in the follicles that are predicted for ovulation in 9 h. Iwamatsu (2006) previously presented a schematic model for the follicular envelope of the fish preovulatory follicle with a theca cell layer. In this review, we will discuss the proteolytic degradation process of the envelope extracellular matrix (ECM) in medaka ovulation based on the model illustrated in Fig. 1.

Differences exist in the follicle envelope between teleosts and mammals. In the preovulatory follicles of 
mammalian species, several layers are discriminated at the rupture site from the outside to the apical region: surface epithelium, tunica albuginea, theca externa, theca interna, basement membrane and granulosa. The surface epithelium is a single layer of cuboidal epithelial cells that cover the entire surface of the ovary and are loosely attached to a thin basement membrane at the surface of the tunica albuginea (Espey \& Richards 2006). Granulosa cells are further divided into two groups: ordinary granulosa cells that line the inside of the basement membrane in several cell layers and cumulus granulosa cells that surround and directly contact the oocyte. The theca externa and theca interna structures consist of several cell layers. Another interesting feature of mature mammalian follicles is the presence of the follicular cavity or antrum that contains liquid convergence. Fibroblasts are densely found in the tunica albuginea and theca externa, while they are sparse in the theca interna (Espey \& Richards 2006).

\section{Distribution of ECM components in the follicle envelope in teleosts}

Ovarian follicle ECM components have been extensively characterized in mammalian species (Espey 1999, Rodgers et al. 2003, Irving-Rodgers \& Rodgers 2006, Berkholtz et al. 2006, Curry \& Smith 2006). In the follicular envelope of a fully grown preovulatory follicle, ECM proteins are rich in the theca cell layer as well as in the basement membrane. Although a variety of molecular species of ECM proteins are found to be present in the envelope (Rodgers et al. 2003), collagen type I is the major ECM protein in the theca cell layer while collagen type IV and laminin are the two dominant ECM proteins in the basement membrane (Lind et al. 2006a). In teleosts, there are several reports that describe the localization of ECM proteins in the ovarian follicle. In the study of early ovarian regression using Prochilodus argenteus, laminin and collagen type IV were identified as the major constituents of the basement membrane of the ovulatory follicle (Thomé et al. 2010). Furthermore, the intensity of immunochemical staining associated with collagen type IV decreased significantly in the follicle 3 days after ovulation (Santos et al. 2008). Localization of three ECM proteins (collagen type I, collagen type IV and laminin) in the follicle envelope of preovulatory follicles was also investigated in the medaka (Horiguchi et al. 2008, Kato et al. 2010, Ogiwara et al. 2015). Immunohistochemical analysis demonstrated that all the ECM proteins were detected in association with a thin layer of theca cells and/or basement membrane, but they were not associated with the granulosa cells of the follicles. This conclusion is supported by co-examining the localization of Mmp15 (Fig. 2). Both collagen type I and collagen type IV expression levels are restricted to the periphery of the follicles and are clearly different from Mmp15 localization. Mmp15 is a marker protein associated with granulosa cells of the medaka periovulatory and postovulatory follicles. Although convincing information on the precise intrafollicular distribution of the ECM proteins has yet to be provided, the results of morphological studies described above, together with biochemical data (Kato et al. 2010, Ogiwara et al. 2015), appear to support strongly the idea that collagen type I is localized in the extracellular space of the theca cell layer while collagen type IV and laminin are the major components of the basement membrane in the fully grown medaka follicle. Using in situ hybridization analysis, collagen type I and collagen type IV were demonstrated to be synthesized
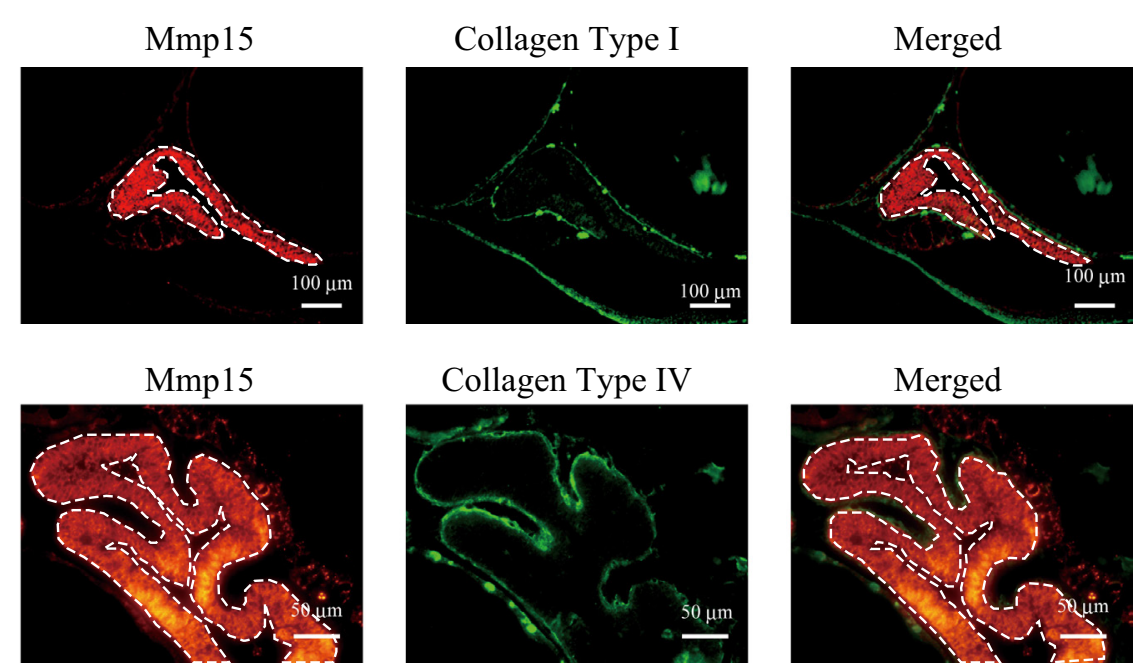

Figure 2 Localization of collagen type I and collagen type IV protein in the ovarian follicle in medaka. Immunohistochemical analysis was performed using paraffin sections of spawning medaka ovaries isolated $19 \mathrm{~h}$ before ovulation. Mmp15, collagen type I and collagen type IV were stained using purified rabbit anti-medaka Mmp15 antibody, rat anti-medaka collagen type I $\alpha 1$ chain antibody or mouse anti-medaka collagen type IV $\alpha 1$ chain antibody, respectively, as primary antibodies. As secondary antibodies, Alexa Fluor 555-conjugated anti-rabbit IgG antibody (for Mmp15), Alexa Fluor 488-conjugated anti-rat IgG antibody (for collagen type I) and Alexa Fluor 488-conjugated anti-mouse IgG antibody (for collagen type IV) were used. As noted in the merged images, both collagen I and collagen IV staining are observed as a thin line that surrounds the staining of Mmp15 (circled by a dotted line), a marker protein for granulosa cells of the fish ovarian follicles around the time of ovulation. 
in the thecal cells (Kato et al. 2010) while laminin was produced in the granulosa cells of the preovulatory follicle in the medaka ovary (Ogiwara et al. 2015).

\section{ECM hydrolysis in follicle rupture during teleost ovulation}

Collagenous tissue degradation in the follicle layer of periovulatory follicles is required for the mature oocyte to be released. The first indication that proteolytic enzymes were involved in ovulation in teleost fish was reported in brook trout (Berndtson \& Goetz 1988). The authors found that in the casein-zymographic analysis, follicle wall extracts had at least six separate polypeptide bands with proteolytic enzyme activity and that the activities associated with the polypeptides were completely or partially inhibited by metallo- and collagenolytic protease inhibitors and serine protease inhibitors. The same authors further confirmed these observations using other teleost species (Berndtson \& Goetz 1990). Collagenolytic activities of the follicle wall extracts increased significantly in both brook trout and yellow perch prior to ovulation and remained elevated after ovulation. Implication of kallikrein-like serine protease (KT-14) in trout ovulation was also documented (Hajnik et al. 1998). In more recent studies using microarray analysis (Bobe et al. 2006) and genome-wide differential gene expression analysis (Liu et al. 2017, Klangnurak \& Tokumoto 2017), upregulated or downregulated genes in the ovulatory follicle at ovulation were identified. Transcripts for serine protease 23 (sp23) and disintegrin and metalloproteinase domain 22 (adam22) were found to be induced in the periovulatory follicle of rainbow trout (Bobe et al. 2006). A drastic change in gene expression was observed for a disintegrin-like and metalloproteinase with thrombospondin type 1 motif 9 (adamts9), adamts $8 b$ and mmp9 (also known as gelatinase $B$ ) in the periovulatory follicle of zebrafish (Liu et al. 2017). Recent studies have reported the importance of Mmp2 (also known as gelatinase A) and KT-14 for ovulation in brook trout and brown trout (Crespo et al. 2010, 2013, 2015). In addition, upregulation of transcripts encoding various intrinsic protease inhibitors at the time of ovulation has been reported for several teleost species. Levels of ovarian transcripts of trout ovulatory protein-1 and -2 (TOP-1 and TOP-2), proteins that share homology with antileukoproteinases (a group of mammalian leukocytic protease inhibitors), dramatically increased as the time of ovulation neared (Garczynski \& Goetz 1997, Coffman et al. 2000). Serine proteinase inhibitor family $\mathrm{E}$ member 1 (serpine1) and tissue inhibitor of metalloproteinase-2 (timp2) were also shown to be upregulated during ovulation in zebrafish (Liu et al. 2017). Involvement of TOP-2 in brook trout and brown trout ovulation has been suggested (Crespo et al. 2015). These findings indicate that proteolytic enzymes, together with intrinsic proteinase inhibitors, play a role in ECM degradation in follicle rupture during teleost ovulation.

In the past decade, the ECM degradation mechanism that regulates follicle rupture has been explored in the medaka (Ogiwara et al. 2005, 2012, 2015). The rupture of follicles in the fish is accomplished by the sequential action of two proteolytic enzyme systems, the urokinase-type plasminogen activator-1 (Plau1)/ plasmin system and the matrix metalloproteinase (MMP) system. These enzymes are controlled by plasminogen activator inhibitor-1 (Pai1) and tissue inhibitor of metalloproteinase-2b (Timp2b), respectively. A follicle rupture model for medaka ovulation is shown in Fig. 3.

During the 24-h spawning cycle of the mature female fish, post-vitellogenic (or preovulatory) follicles undergo a surge of LH approximately $18 \mathrm{~h}$ before ovulation (Iwamatsu 1978, Ogiwara et al. 2013). A series of ECM degradation reactions occur in the follicle wall approximately $10 \mathrm{~h}$ after the LH surge, which lasts until ovulation. The degradation process involves many proteins; most of them are derived from the oocyte and the granulosa cells of the follicle, while plasminogen is thought to have an extraovarian origin. In the follicle that has undergone LH surge, the Plau1/plasmin and the MMP proteolytic enzyme system both remain inactive until $7 \mathrm{~h}$ before ovulation due to the inhibitory effects of the respective inhibitors (Pai1 for Plau1 and Timp2b for MMP) (Fig. 3A). Inactive precursor Plau1 (ProPlau1) is constitutively synthesized in and secreted from the oocyte of the follicle throughout the 24-h spawning cycle. The secreted ProPlau1 is likely converted to active Plau1 through proteolytic processing by an unknown protease. However, the resulting active Plau1 is immediately inactivated by Pai1, which is secreted from the granulosa cells of the follicle. This prevents Plau1 from attacking egg membrane-bound plasminogen, which is presumably derived from the liver via the circulatory system, thus preventing the generation of active plasmin in the follicle. During this period, the MMP system is also kept inactive. Mmp2 (also known as gelatinase $\mathrm{A}$ ) is constitutively synthesized in the oocyte as its inactive precursor proMmp2. ProMmp2 is then activated by membrane-bound Mmp14 (also known as Mt1-mmp) which is expressed constitutively on the cell surface of the oocyte. However, Timp $2 b$, which is also produced by and secreted from the oocyte to the extracellular space of the follicle, binds to Mmp2 to suppress the enzyme activity. Approximately $7 \mathrm{~h}$ before ovulation, expression of Pai1 in the granulosa cells of the follicle is reduced, resulting in low levels of secreted Pai1 in the extracellular space (Fig. 3B). Hence, Plau1 can escape from the inhibitory effect of Pai1. Active Plau1 is now capable of converting egg membranebound plasminogen to the active enzyme plasmin, which in turn hydrolyzes laminin, one of the major ECM components of the follicle basement membrane. 


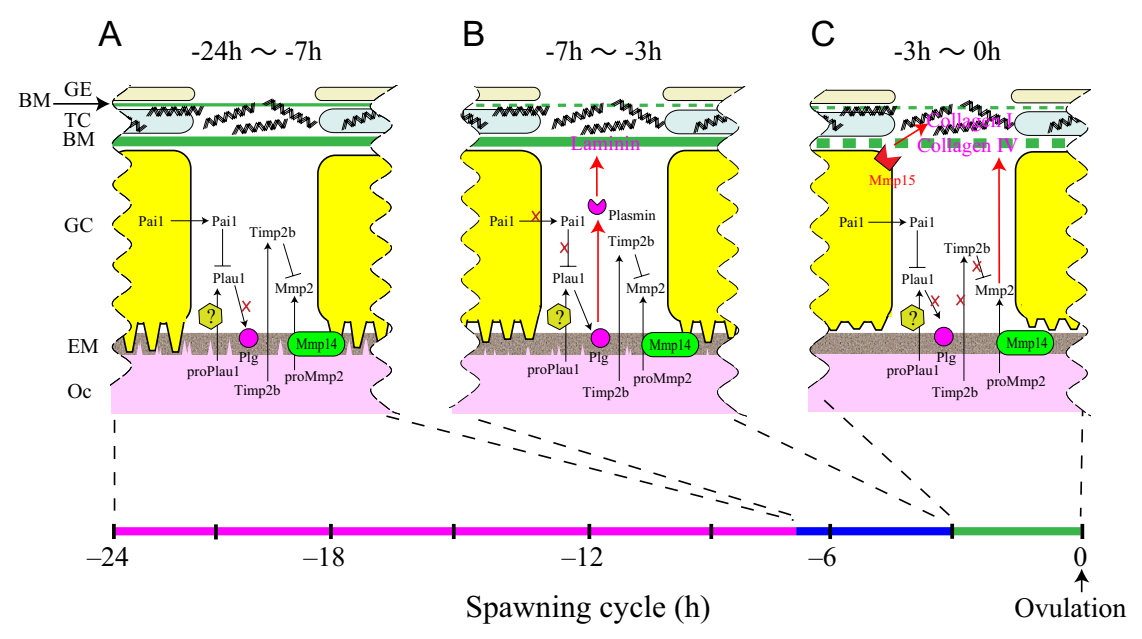

Figure $3 \mathrm{~A}$ schematic representation of the two-step ECM degradation model for follicle rupture during medaka ovulation. (A) In post-vitellogenic follicles and preovulatory follicles, hydrolysis of follicular envelope ECM proteins by proteolytic enzymes is inhibited with the intrinsic protease inhibitors, Pai1 and Timp2 b, until $7 \mathrm{~h}$ before ovulation. (B) The Plau1/plasmin proteolytic system is activated due to the cessation of Pai1 synthesis and secretion from granulosa cells in the follicles. Degradation of laminin, one of the major components constituting the basement membrane, occurs for several hours until the synthesis and secretion of Pai1 in the granulosa cells resume. (C) The MMP proteolytic system is activated in the follicles immediately prior to ovulation because of reduced Timp2b secretion from the oocyte. During this period, collagen type IV (which remains in the basement membrane after the previous Plau1/plasmin hydrolysis event) and collagen type I (which resides throughout the layer of theca cells) are effectively degraded. BM, basement membrane; EM, egg membrane; GC, granulosa cell; GE, germinal epithelium; Oc, oocyte cytoplasm; TC, theca cell.
Collagen type IV, another major ECM component of the basement membrane, is not degraded by plasmin at all at this time period. Reduced expression levels of Pai1 in the granulosa cells last for several hours. Pai1 expression and secretion resume approximately $3 \mathrm{~h}$ before ovulation, ceasing the conversion of plasminogen to plasmin due to the suppression of Plau1 activity by newly synthesized Pai1. Meanwhile, the MMP proteolytic system in the follicle still remains inactive. However, during the last $3 \mathrm{~h}$ of the 24-h spawning cycle, active Mmp2 and Mmp15 (also known as Mt2-mmp) appear in the follicle (Fig. 3C). During this period, levels of Timp2b in the extracellular space of the periovulatory follicle are drastically reduced. As a result, Mmp2 is freed from inhibition by the intrinsic proteinase inhibitor, which allows the protease to degrade collagen type IV remaining in the basement membrane. A membranebound protease Mmp15 is expressed on the cell surface of the granulosa cells at this time. Collagen type I that is in the extracellular space of the theca cell layer is effectively degraded by Mmp15. Mmp15 attack on collagen type $\mathrm{I}$ is feasible only after the breakdown of the basement membrane. Based on the findings that sequential actions of two distinct proteolytic enzyme systems are required for follicle ovulation, we have proposed a 'two-step ECM hydrolysis mechanism' for follicle rupture during ovulation in the medaka (Ogiwara et al. 2015).

The surface germinal epithelial cell layer and the basement membrane lining the cell layer at the site of rupture also need to be disintegrated in order for the oocyte to be expelled from the follicle. However, there is currently little information regarding this process for medaka or any other teleost species. As described above, a series of proteolytic reactions required for follicle rupture during ovulation in medaka starts at the rupture site approximately $7 \mathrm{~h}$ before ovulation. At present, we hypothesize that the basement membrane between the epithelial cell layer and the theca cell layer at the rupture site may have already been degraded by a yet-undefined mechanism by this time.

Table 1 summarizes studies that have investigated the role of proteolytic enzymes and their inhibitors involved in fish ovulation.

\section{Endocrine regulation of ECM hydrolysis of the follicle wall during ovulation}

The role of LH in teleost ovulation is illustrated by the ability of fish recombinant $\mathrm{LH}$ to induce ovulation in vitro in medaka (Ogiwara et al. 2013) and brook trout (Crespo et al. 2013). Further, the essential roles of the gonadotropin and its cognate receptor have been demonstrated by gene knockout experiments using zebrafish (Chu et al. 2014, Zhang et al. 2015) and medaka (Takahashi et al. 2016).

In teleosts, two progestins, $17 \alpha, 20 \beta$-dihydroxy-4pregnen-3-one $(17,20 \beta \mathrm{P})$ in most fish and $17,20 \beta, 21$ trihydroxy-4-pregnen-3-one (20ß-S) in some fish, are known to act as maturation-inducing hormones (MIH) or maturation-inducing steroids (MIS) (Nagahama 
Table 1 A summary of the ECM degradation mechanisms involved in fish ovulation.

Time window of ECM protease expression in $24 \mathrm{~h}$ Ovulation/spawning cycle of medaka*

$7 \mathrm{~h}$ to $3 \mathrm{~h}$ before ovulation

i) Proteases involved

Plau1

Plasmin

ii) Proteolytic events occurring during this period Proteolytic activation of proPlau1 by a yet unknown protease Proteolytic activation of plasminogen by active Plau1 Basement membrane laminin degradation by plasmin

iii) Intrinsic protease inhibitor involved Pai1

$3 \mathrm{~h}$ to $\mathrm{Oh}$ before ovulation

i) Proteases involved Mmp14

Mmp2 Mmp15

ii) Proteolytic events occurring during this period Proteolytic activation of proMmp2 by Mmp14 Basement membrane collagen IV degradation by $\mathrm{Mmp} 2$ Theca cell layer collagen I degradation by Mmp15

iii) Intrinsic protease inhibitor involved Timp2
Proteases and intrinsic inhibitors presumed to be involved in the ovulation of other teleosts

Proteases:

KT-14 (brook trout) (Hajnik et al. 1998, Crespo et al. 2010, 2013, 2015)

Serine protease 23 (rainbow trout) (Bobe et al. 2006)

Adam22 (rainbow trout) (Bobe et al. 2006)

Adam 9 (zebrafish) (Liu et al. 2017)

Adamts8b (zebrafish) (Liu et al. 2017)

Mmp2 (trout) (Crespo et al. 2015)

Intrinsic inhibitors:

TOP-1 and -2 (brook trout) (Garczynski \& Goetz 1997, Coffman et al. 2000)

TOP-2 (brown trout) (Crespo et al. 2015)

Timp2 (zebrafish) (Liu et al. 2017)

Serpine1 (zebrafish) (Liu et al. 2017)

*From the studies of Ogiwara et al. $(2005,2013,2015)$. See the text for details.

\& Yamashita 2008). These progestins are actively synthesized in the preovulatory follicles after theovulatory LH surge and induce oocyte maturation and ovulation. The steroids induce oocyte maturation by binding to a G-protein-coupled membrane-bound progestin receptor $(\mathrm{mPR})$ expressed on the cell membrane of the oocyte (Zhu et al. 2003, 2008, Tokumoto et al. 2006, Nagahama \& Yamashita 2008, Senthilkumaran 2011, Thomas 2012). Progestin-activated mPR is believed to act via nongenomic pathways to induce oocyte maturation. On the other hand, progestins also activate a series of reactions that are closely associated with ovulation in the follicle cells by binding to a nuclear progestin receptor (Pgr, also known as nPR) which acts as a ligand-activated transcription factor. Progestin-activated Pgr plays a key role in the expression of various factors and proteins required for ovulation through a genomic mechanism (Hagiwara et al. 2014, Zhu et al. 2015, Tang et al. 2016, Ogiwara \& Takahashi 2017, Liu et al. 2017).

Recently, a mechanism for the Pgr-regulated expression of ovulatory proteases has been investigated using medaka (Ogiwara \& Takahashi 2017) (Fig. 4). As described in the preceding section, at least five distinct proteases (Plau1, plasmin, Mmp2, Mmp14 and Mmp15) participate in the degradation of follicle wall ECM in the fish ovulation. Among them, Mmp15 is the only protease that is drastically induced in the granulosa cells of preovulatory follicles by the LH surge. When the LH stimulus occurs approximately $18 \mathrm{~h}$ before ovulation, intracellular cAMP levels are immediately elevated in the cells, which leads to pgr mRNA and protein expression in the next several hours. Pgr is expressed in the granulosa cells of the follicles from $13 \mathrm{~h}$ to $3 \mathrm{~h}$ before ovulation, and the maximum level of expression occurs approximately $8 \mathrm{~h}$ before ovulation (Hagiwara et al., 2014). We have shown that in vitro experiments using isolated post-vitellogenic follicles, pgr/Pgr expression can be induced by treatment with recombinant medaka $\mathrm{LH}$, but $\mathrm{LH}$-induced expression of the gene is not affected by adding protein kinase A inhibitor $\mathrm{H}-89$ into the culture (K Ogiwara \& T Takahashi unpublished observation). Thus, the pathway activated by cAMP is perhaps independent of protein kinase A. Further investigations are warranted to establish the mechanism

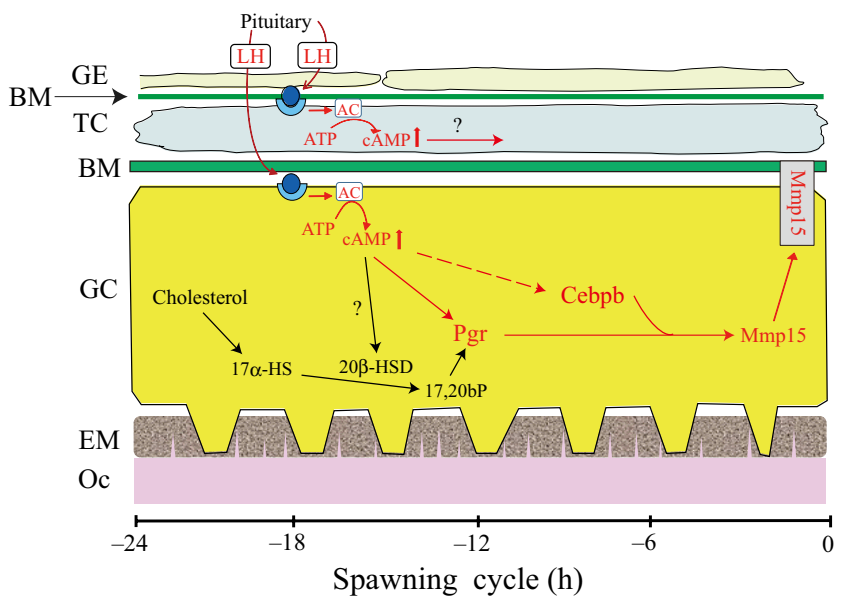

Figure $4 \mathrm{~A}$ schematic representation of $\mathrm{Mmp} 15$ expression induced by LH surge in the preovulatory follicle in medaka. Timing of appearance and/or action of various factors involved in the induction of Mmp15 is shown in the 24-h spawning cycle of the female fish. The presence of $\mathrm{LH}$ receptor in both theca cells and granulosa cells of preovulatory follicles was confirmed (Ogiwara et al. 2013), but the role of theca cells in follicle rupture during ovulation in the medaka is not clear at present. See the text for details. 
of how elevated cAMP levels within the granulosa cells cause $p g r / P g r$ expression changes.

Regarding the regulation of progestin synthesis in the preovulatory follicles of fish, a dramatic shift in the steroidogenic pathway from estradiol- $17 \beta$ to $17,20 \beta \mathrm{P}$ or 20ß-S occurs after the LH surge (Nagahama \& Yamashita 2008). It is generally thought that synthesis of $17 \alpha$-hydroxyprogesterone from the precursor cholesterol occurs in the theca cells and that the last step of conversion from $17 \alpha$-hydroxyprogesterone to $17,20 \beta \mathrm{P}$ or $20 \beta-\mathrm{S}$ is catalyzed by an enzyme present in the granulosa cells. In the medaka, $17,20 \beta \mathrm{P}$ is a known naturally occurring progestin that functions as a mediator of oocyte maturation and ovulation (Sakai et al. 1987, Fukada et al. 1994). In this fish, removal of all follicular constituents, but not removal of the thecal layer alone, prevented gonadotropin-induced maturation of oocytes. Denuded oocytes undergo maturation in response to gonadotropin when co-cultured with isolated granulosa cells (Iwamatsu 1980). In addition, granulosa cells isolated from large ovarian follicles of daily spawning medaka at $8.5 \mathrm{~h}$, but not $2.5 \mathrm{~h}$, after the onset of light produces immunoreactive materials detectable with anti-progesterone antibody and anti-17 $\alpha$ hydroxyprogesterone antibody (Onitake \& Iwamatsu 1986). These results suggest that medaka granulosa cells alone are capable of producing $17,20 \beta \mathrm{P}$ in response to gonadotropin. Consistent with this notion, our group (K Ogiwara \& T Takahashi 2016, unpublished results) and another group (Y Nagahama 2015, personal communication) found that P450scc, 3 $\beta$-hydroxysteroid dehydrogenase (type 1) and 20ß-hydroxysteroid dehydrogenase, the enzymes responsible for $17,20 \beta \mathrm{P}$ synthesis (Nagahama \& Yamashita 2008), were all expressed in the granulosa cells of the follicles that had undergone an LH surge in vivo. This situation appears different from that in salmonids, where both thecal and granulosa cells are necessary for the follicular production of $17,20 \beta \mathrm{P}$ in response to gonadotropin (Nagahama \& Yamashita 2008). In the current model, we hypothesize that the granulosa cells are the sole contributors to the production of $17,20 \beta \mathrm{P}$. In the medaka, $17,20 \beta \mathrm{P}$ production is high in the $\mathrm{LH}$-stimulated follicles between 14 and $6 \mathrm{~h}$ before ovulation (Sakai et al. 1988, Fukada et al. 1994). The timing of $17,20 \beta \mathrm{P}$ production in the follicle almost completely overlaps with the synthesis of Pgr. This allows Pgr to associate readily with its ligand steroid $17,20 \beta \mathrm{P}$ to become an active transcription factor. The mechanism behind the induction of $17,20 \beta \mathrm{P}$ upon LH stimulation of the follicles is not known in the fish. In amago salmon, an increase in intracellular cAMP levels in the granulosa cells was demonstrated to cause the induction of 20 $\beta$-hydroxysteroid dehydrogenase (Nagahama et al. 1985, Nagahama 1997). In analogy, we tentatively speculate that increased cAMP levels in the cells immediately after LH stimulation may result in de novo synthesis of Pgr as well as production of $17,20 \beta \mathrm{P}$ in the follicles. Considering the occurrence of Pgr protein between 13 and $3 \mathrm{~h}$ before ovulation and the expression of $17,20 \beta \mathrm{P}$ between 14 and $6 \mathrm{~h}$ before ovulation in the cells, active transcription factor Pgr, a complex of Pgr and $17,20 \beta \mathrm{P}$, should be formed by $13 \mathrm{~h}$ before ovulation at the latest in the granulosa cells. Activated Pgr then contributes to the expression of mmp15 and pai1, $\mathrm{LH}$-inducible genes in the granulosa cells of ovulating follicles. The roles for Pgr in the expression of these two genes will be described below.

The binding of active Pgr to the promoter region of the mmp15 gene was confirmed by ChIP assays (Ogiwara \& Takahashi 2017). Significant binding was observed at two positions containing putative progesterone response elements that were located within $0.5 \mathrm{~kb}$ upstream of the mmp 15 transcription start site. Pgr binding occurs at $4 \mathrm{~h}$, but not $13 \mathrm{~h}$, before ovulation. This late timing of Pgr binding to the promoter region is consistent with the previous finding that mmp 15 mRNA became detectable as late as $2 \mathrm{~h}$ before ovulation in vivo (Ogiwara et al. 2005). The considerably long time lag from pgr gene activation to $m m p 15$ gene expression could be explained by several factors. We found that Pgr synthesized in the granulosa cells is phosphorylated and that only the phosphorylated form of Pgr is involved in the expression of mmp15 (K Ogiwara \& T Takahashi, unpublished observations). Phosphorylated Pgr becomes detectable in the cells on and after $9 \mathrm{~h}$ before the expected ovulation time in the 24-h spawning cycle. Furthermore, the transcription factor CCAAT/enhancer-binding protein $\beta$ (Cebpb) is an additional factor critically involved in the induction of mmp15 expression. Cebpb expression is also regulated by $\mathrm{LH}$ though its $\mathrm{LH}$-induced expression is not Pgr dependent. Therefore, Cebpb needs to be synthesized in a Pgr-independent manner prior to the activation of the mmp15 gene. Undoubtedly, this causes a late appearance of Mmp15 (Ogiwara \& Takahashi 2017). However, the above explanations are not convincing enough to explain the late onset of mmp15 transcription in vivo. We currently speculate that there may be additional factors required for the timing of mmp15 expression. Figure 4 illustrates the pathway of Mmp15 induction in the granulosa cells of ovulating follicles that undergo an LH surge.

Of the two intrinsic protease inhibitors (Pai1 and Timp2b) involved in follicle rupture during ovulation in the medaka, Pai1 expression is induced in the preovulatory follicles after the surge of $\mathrm{LH}$ (Ogiwara et al. 2015). The LH-induced expression of Pai 1 is mediated by $17,20 \beta \mathrm{P}$-activated Pgr, and this hypothesis is supported by a number of observations. First, medaka-recombinant Lh (rLh) treatment of preovulatory follicles induces pai1 mRNA expression, but the rLh-induced pai1 expression is inhibited by the addition of trilostane, an inhibitor of $3 \beta$-hydroxysteroid dehydrogenase that catalyzes the conversion of pregnenolone, 17-hydroxy-progesterone and dehydroepiandrosterone to progesterone, 17-hydroxy- 
progesterone and androstenedione, respectively. Additionally, the inhibitory effect of trilostane on pai1 expression in the rLh-treated follicles is nullified if the follicles are incubated together with 17,20ßP. Furthermore, $\mathrm{LH}$-induced pai1 expression is inhibited with RU486, a nuclear progestin receptor antagonist for medaka Pgr (Hagiwara et al. 2014). More importantly, we found the binding of Pgr to the pai1 promoter region by ChIP analysis (K Ogiwara \& T Takahashi 2016, unpublished data). In this context, it should be noted that pai1 expression in the ovarian follicle of the fish may be regulated in various ways. In situ hybridization analysis revealed that pai1 mRNA was expressed in the oocyte cytoplasm in small-sized follicles (previtellogenic phase, stages III-IV) and medium-sized follicles (vitellogenic phase, stages $\mathrm{V}-\mathrm{VIII}$ ), but the gene expression in the oocyte declined progressively with the growth of the follicles. In large-sized follicles (post-vitellogenic phase, stages IX-X), pai1 mRNA expression is almost exclusively localized in the granulosa cells of the follicle layer (Ogiwara et al. 2015). These findings suggest that LH-induced and Pgr-mediated pai1 expression observed in the granulosa cells of periovulatory follicles are not the sole mechanisms in ovarian follicles of the fish. Another mechanism may be responsible for the expression of pai1 mRNA in the oocytes of small- and medium-sized growing follicles, which are under the influence of FSH. At present, it is not known how pai1 mRNA expression is regulated in growing follicles without $\mathrm{LH}$ stimulation. In the post-vitellogenic follicles, Pai1 secreted from the granulosa cells inhibits Plau1 activity. This prevents the activation of plasminogen in the follicle. However, gradual decrease in Pai1 synthesis and secretion from the granulosa cells eventually results in the activation of the Plau1/plasmin system. In several hours, Pai1 synthesis resumes in the cells of ovulating follicles in an LH- and Pgr-dependent manner in response to the LH surge. Here, an additional question is posed concerning the regulation of Pai1 expression in the granulosa cells of the follicles that are destined to ovulate. Our results suggest that two distinct mechanisms may work to regulate Pai1 expression in the cells of the follicles. Pai1 expression may be regulated in an $\mathrm{LH}$-independent manner in the granulosa cells of post-vitellogenic follicles, but its regulation may be switched to an LH-dependent manner in the follicular cells after the LH surge.

An attempt to search for key regulators that mediate the many effects of the LH surge within the preovulatory follicle was performed using brown trout (Crespo et al. 2010). The study determined the important roles of an inflammatory cytokine tumor necrosis factor- $\alpha$ (TNF $\alpha)$ in follicle weakening, ovarian rupture and oocyte expulsion during ovulation. A study by the same group further reported that $\mathrm{LH}$-stimulated mRNA expression levels of genes known to have a crucial role in the degradation of follicle wall structure (Crespo et al. 2013), including $m m p 2, m m p 9$, adamts 1, plasminogen and timp2. More recently, it was demonstrated that TNF $\alpha$ is also induced in the follicle by $\mathrm{LH}$ and that TNF $\alpha$ in turn controls the expression of genes, such as mmp2, kt14 and top2 (Crespo et al. 2015).

An implication of protein kinase C (PKC) in the ovulatory process has been reported for yellow perch (Berndtson et al. 1989), goldfish (Goetz 1993), brook trout (Planas et al. 1997, Coffman et al. 2000) and Atlantic croaker (Patiño et al. 2003). In the context of proteolysis and its regulation, the finding of Berndtson et al. (1989) should be noted. The authors found that incubation of isolated yellow perch follicles with the PKC activator phorbol 12-myristate 13-acetate (PMA) stimulated the rate of follicle ovulation and that protease activity associated with one major $66-\mathrm{kDa}$ protease protein increased in the medium during incubation with the PKC activator.

\section{Perspective}

The site of rupture is in the apical most region of the follicle. In mammals, follicle rupture during ovulation is known to be accompanied by alterations in blood flow and vascular permeability of the capillaries distributed in the theca cell layer of the follicle (Tsafriri \& Dekel 1994). Various vasoactive substances have been documented to affect the rupture process (Tsafriri \& Reich 1999). Of interest is a recent finding using mice by Migone et al. (2016) indicating that vasoconstriction of thecal vessels at the apex of the preovulatory follicle is necessary for follicle rupture at ovulation. Furthermore, the report provides evidence that endothelin 2 induces vasoconstriction to allow follicle rupture. On the basis of the results, the authors of that paper have proposed a possible mechanism for destruction of a small region at the apex; vasoconstriction at the apex causes the localized depletion of components, including protease inhibitors derived from serum, facilitating proteolytic degradation of follicle wall ECM by active proteases. Unfortunately, little is known about the mechanism by which the rupture site is precisely localized in teleosts. Future studies are needed to reveal this fundamental problem.

It is now clear that follicle rupture in medaka ovulation is a two-step ECM degradation mechanism involving two distinct proteolytic enzyme systems, the Plau1/plasmin system and the MMP system. These systems are temporally activated in the ovulating follicle when intrafollicular levels of their intrinsic inhibitors are lowered. However, information about the follicle rupture process remains unknown for other teleost species. Therefore, it is presently not clear whether follicle ECM degradation accompanying ovulation in other fish occurs in a manner similar to medaka. Nevertheless, there seems to be some consistency in the proteolytic enzyme system involved in the degradation of ECM in ovulating follicles between medaka and 
trout. In the pioneering work of Berndtson \& Goetz (1988), proteases responsible for brook trout ovulation were determined to be metalloprotease(s) and serine protease(s). In agreement with their statement made 30 years ago, three Mmp enzymes (Mmp2, Mmp14 and Mmp15, which all belong to the metalloprotease family) and Plau1 and plasmin (which are both categorized in the serine protease family) were identified as proteases indispensable for follicle rupture in medaka ovulation (Ogiwara et al. 2005, 2012, 2015). Consistent with the studies about medaka ovulation, Crespo et al. (2015) have recently reported the possibility that Mmp2 may be one of the proteases involved in brown trout ovulation.

The transcription factor Pgr is an essential mediator of the LH surge in medaka (Hagiwara et al. 2014, Ogiwara \& Takahashi 2017) and zebrafish ovulation (Zhu et al. 2015, Tang et al. 2016, Liu et al. 2017). At present, only several genes that are expressed in a Pgr-dependent manner at teleost ovulation have been identified to date: $m m p 15$, pai1 and ptger $4 b$ for medaka (Hagiwara et al. 2014, Ogiwara \& Takahashi 2017) and ptger4b for zebrafish (Tang et al. 2016). Future studies that characterize genes/proteins expressed under the control of Pgr in preovulatory follicles would contribute greatly to the overall understanding of the mechanisms that regulate ovulation in teleosts. In addition, defining a signaling pathway activated after the $\mathrm{LH}$ surge in granulosa cells to synthesize Pgr remains a challenge.

Another important mediator of the LH surge is TNF $\alpha$, as recently documented for brown trout ovulation (Crespo et al. 2015). The authors proposed that TNF $\alpha$ has the dual role of promoting collagen breakdown and cellular death in the trout preovulatory follicle as a requisite for ovulation. Here, an intriguing question arises as to the relationship between TNF $\alpha$ and Pgr in the ovulatory process in teleosts. It is worthwhile to examine whether TNF $\alpha$ and Pgr have a role, independently or in combination, in the expression of proteolytic enzymes required for the process of follicle rupture.

Activation of PKC is shown to be involved in ovulation in various teleost species (Berndtson et al. 1989, Goetz 1993, Planas et al. 1997, Coffman et al. 2000, Patiño et al. 2003). In Atlantic croaker, the PKC pathway is necessary for $\mathrm{MIH}$-induced ovulation (Patiño et al. 2003). Considering that MIH is the ligand of Pgr and that $\mathrm{MIH}$-activated Pgr could induce various ovulationrelated genes, studies addressing the mechanism of how activation of the PKC pathway leads to ovulation would provide valuable information.

A currently unaddressed issue in follicle rupture during ovulation in medaka concerns the role of surface germinal epithelial cells and the associated basement membrane underneath at the rupture site. This basement membrane must be a target of proteolytic enzymes as well. Hydrolysis of the ECM components constituting the membrane has been completed prior to the onset of follicular envelope ECM degradation involving the Plau1/ plasmin system and the Mmp system. Identification and regulation of proteolytic enzyme activities responsible for the breakdown of the basement membrane supporting the epithelial cells remain to be studied.

There is persuasive evidence that prostaglandins are also critically involved in follicle rupture during ovulation in vertebrates (Sirois et al. 2004a,b, Richards 2005, Stouffer et al. 2007, Sugimoto et al. 2015). The role for prostaglandins in teleost ovulation has been recently reviewed (Takahashi et al. 2018). In medaka, Ptger $4 b$, a prostaglandin $E_{2}$ receptor isoform of Ptger4, is expressed in the granulosa cells of ovulating follicles and is activated with its ligand prostaglandin $E_{2}$ at the time of ovulation (Fujimori et al. 2011,2012, Hagiwara et al. 2014). The activated Ptger $4 b$ receptor results in the rearrangement of intracellular actin cytoskeleton in the cells, for which the activation of melatonin receptor-1 subtype (Mtnr1a-a) is also required (Ogiwara \& Takahashi 2016). Interestingly, the proteolytic enzyme system and prostaglandin receptor signaling pathways are activated in parallel in the ovulating follicles in the fish. Emerging evidence indicates that, in addition to Mmp15 and Pai1, the Ptger4b receptor is also a follicle rupture player downstream of the transcription factor Pgr (Hagiwara et al. 2014). How the timing of activation of these two events are regulated at the molecular level in the ovulating follicle remains to be answered.

Because follicle rupture during ovulation is a biological process ubiquitously observed in both vertebrate and invertebrate animals that sexually reproduce, it may be beneficial to determine the extent to which the rupture mechanism is conserved in the animal kingdom. Few studies have been published addressing ovulation of invertebrate animals. In contrast, a large number of studies have been conducted to seek proteolytic enzymes pivotal for follicle rupture in various mammals (Ny et al. 2002, Smith et al. 2002, Ohnishi et al. 2005, Curry \& Smith 2006, Espey \& Richards 2006, Liu et al. 2013). As in medaka ovulation, the involvement of the plasminogen activator (PA)/ plasmin system and the MMP system, either separately or in combination, in the rupture of the follicular envelope at ovulation has been repeatedly mentioned. However, the biological significance of the PA/plasmin system and the MMP system in mammalian ovulation remains controversial (Espey \& Richards 2006, Liu et al. 2013). Information on proteolytic enzymes involved in follicle rupture during human ovulation is limited due to the difficulties of collecting ovarian tissues. However, studies have been conducted to examine the expression and distribution of proteolytic enzymes and intrinsic inhibitors using follicular tissues collected from women undergoing laparoscopic fertilization across the periovulatory period. The specimens are physiologically more relevant than that of granulosa-lutein cells from in vitro fertilization (IVF, Lind et al. 2006b, McCord et al. 2012, Rosewell et al. 2015). The results of these 
studies have revealed the expression of nine MMPs and two species of a disintegrin and metalloproteinase with thrombospondin motifs (ADAMTS) in the granulosa and theca cells: MMP1, MMP2, MMP3, MMP8, MMP9, MMP10, MMP11, MMP13, MP19, ADAMTS1 and ADAMTS9. In addition, the expression of TIMP1, TIMP2 and TIMP3 in the cells has been documented (Lind et al. 2006a, Rosewell et al. 2013). Among them, the expression levels of MMP10 (McCord et al. 2012), MMP1 and MMP19 (Rosewell et al. 2015), TIMP1 (Lind et al. 2006b) and TIMP3 (Rosewell et al. 2013) were found to increase in the cells as the time of ovulation approached. Another interesting finding obtained using the same human experimental system is that tissue factor pathway inhibitor 2 (TFPI2), a Kunitz-type serine protease inhibitor, is dramatically induced in human granulosa and theca cells of periovulatory follicles by the administration of human chorionic gonadotropin (Puttabyatappa et al. 2017). Further, TFPI2 knockdown leads to an increase in plasmin activity in rat granulosa cell-conditioned media, suggesting that TFPI2 could regulate plasmin activity in the human ovary (Puttabyatappa et al. 2017). These findings indicate that, like medaka, both MMPs and plasmin are probably involved in follicle rupture during human ovulation. Further detailed studies of proteolytic events occurring at the apex of the periovulatory follicle in human ovulation will clarify the commonality and difference in follicle rupture mechanisms between humans and medaka. Nevertheless, reproductive biologists appear to assume that at least MMPs may have a significant function in the degradation of the collagenous connective tissue in the follicle wall across mammalian species (Espey \& Richards 2006, Liu et al. 2013, Puttabyatappa et al. 2014, Rosewell et al. 2015). This leads to a speculation that the functional role of the MMP system in the rupture may be conserved from teleosts to mammals. Future studies defining a precise role for MMPs in the follicle wall ECM degradation during mammalian ovulation would verify the assumption that the rupture of the follicles in teleost species may represent a prototype for follicle rupture in mammalian ovulation.

An additional future problem concerns the interrelation between the oocyte and follicle cells in teleost ovulation. Most of the proteases and their inhibitors responsible for follicle rupture during medaka ovulation are derived either from the oocyte or granulosa cells. This indicates that the oocyte and the follicle cells are both involved in the rupture process. Interestingly, all the genes/proteins that are induced by the surge of LH are of granulosa cell origin. The timing and order of expression of the genes in the cells appear to be harmonized with the progress of oocyte maturation (Ogiwara et al. 2015, Ogiwara \& Takahashi 2017). Here, a question arises as to whether factors derived from the oocyte undergoing the maturation have a role in the regulated expression of the genes in the granulosa cells of ovulating follicles. To solve this problem, the teleost medaka may serve as a suitable experimental model.

\section{Conclusions}

Over the past three decades, our knowledge of follicle rupture during fish ovulation has significantly increased. In particular, utilization of a small freshwater teleost medaka has contributed greatly to advances in our understanding of this process. We now know that the precise roles of individual proteolytic enzymes and their intrinsic inhibitors in follicle wall ECM degradation during medaka ovulation. In addition, an outline of endocrine regulation governing ECM degradation process has become considerably clearer. However, we are still far away from comprehensive understanding of teleost ovulation, and further investigations are definitely required in the future.

\section{Declaration of interest}

The authors declare that there is no conflict of interest that could be perceived as prejudicing the impartiality of this review.

\section{Funding}

This work was supported by a Grant-in-Aid for Scientific Research 16H04810 from the Ministry of Education, Culture, Sports, Science and Technology of Japan.

\section{Acknowledgements}

The authors express our gratitude to the many wonderful colleagues for their contributions to the work described herein. They also thank Dr Yoshitaka Nagahama, Emeritus Professor of National Institute for Basic Biology, for his valuable comments concerning the manuscript.

\section{References}

Berkholtz CB, Lai BE, Woodruff TK \& Shea LD 2006 Distribution of extracellular marix proteins type I collagen, type IV collagen, fibronectin, and laminin in mouse folliculogenesis. Histochemistry and Cell Biology 126 583-592. (https://doi.org/ 10.1007/s00418-006-0194-1)

Berndtson AK \& Goetz FW 1988 Protease activity in brook trout (Salvelinus fontinalis) follicle walls demonstrated by substrate-polyacrylamide gel electrophoresis. Biology of Reproduction 38 511-516. (https://doi. org/10.1095/biolreprod38.2.511)

Berndtson AK \& Goetz FW 1990 Metallo-protease activity increases prior to ovulation in brook trout (Salvelinus fontinalis) and yellow perch (Perca flavescens) follicle walls. Biology of Reproduction 42 391-398. (https:// doi.org/10.1095/biolreprod42.2.391)

Berndtson AK, Goetz FW \& Duman P 1989 In vitro ovulation, prostaglandin synthesis, and proteolysis in isolated ovarian components of yellow perch (Perca flavescens): effects of $17 \alpha, 20 \beta$-dihydroxy-4-pregnen-3one and phorbol ester. General and Comparative Endocrinology 75 454-465. (https://doi.org/10.1016/0016-6480(89)90181-0)

Bobe J, Montfort J, Nguyen T \& Fostier A 2006 Identification of new participants in the rainbow trout(Oncorhynchus mykiss) oocyte maturation and ovulation processes using cDNA microarrays. Reproductive Biology and Endocrinology 4 39. (https://doi.org/10.1186/1477-7827-4-39) 
Christenson LK, Gunewardena S, Hong X, Spitchak M, Baufeld A \& Vanselow J 2013 Research resource: preovulatory LH surge effects on follicular theca and granulosa transcriptomes. Molecular Endocrinology 27 1153-1171. (https://doi.org/ 10.1210/me.2013-1093)

Chu L, Li J, Liu Y, Hu W \& Cheng CH 2014 Targeted gene disruption in zebrafish reveals noncanonical functions of $\mathrm{LH}$ signaling in reproduction. Molecular Endocrinology 28 1785-1795. (https://doi.org/10.1210/ me.2014-1061)

Coffman MA, Pinter JH \& Goetz FW 2000 Trout ovulatory proteins: site of synthesis, regulation, and possible biological function. Biology of Reproduction 62 928-838. (https://doi.org/10.1095/biolreprod62.4.928)

Crespo D, Bonnet E, Roher N, MacKenzie SA, Krasnow A, Goetz FW, Bobe J \& Planas JV 2010 Cellular and molecular evidence for a role of tumor necrosis factor alpha in the ovulatory mechanism of trout. Reproductive Biology and Endocrinology 8 34. (https://doi.org/10.1186/1477-7827-834)

Crespo D, Pramanick K, Goetz FW \& Planas JV 2013 Luteinizing hormone stimulation of in vitro ovulation in brook trout (Salvelinus fontinalis) involves follicle contraction and activation of proteolytic genes. General and Comparative Endocrinology 188 175-182. (https://doi. org/10.1016/j.ygcen.2013.02.031)

Crespo D, Goetz FW \& Planas JV 2015 Luteinizing hormone induces ovulation via tumor necrosis factor $\alpha$-dependent increase in prostaglandin $\mathrm{F}_{2 \mathrm{a}}$ in a nonmammalian vertebrate. Scientific Reports 5 14210. (https:// doi.org/10.1038/srep14210)

Curry TE \& Smith MF 2006 Impact of extracellular matrix remodeling on ovulation and the folliculo-luteal transition. Seminars in Reproductive Medicine 24 228-241. (https://doi.org/10.1055/s-2006-948552)

Espey LL 1999 Ovulation. In Encyclopedia of Reproduction, vol. III, pp 605-614. Eds. E Knobil and JD Neill. San Diego: Academic Press.

Espey LL \& Richards JS 2002 Temporal and spatial patterns of ovarian gene transcription following an ovulatory dose of gonadotropin in the rat. Biology of Reproduction 67 1662-1670. (https://doi.org/10.1095/ biolreprod.102.005173)

Espey LL \& Richards JS 2006 Ovulation. In Knobil and Neill's Physiology of Reproduction, edn 3, pp 425-474. Ed JD Neill. Amsterdam: Academic Press.

Fujimori C, Ogiwara K, Hagiwara A, Rajapakse S, Kimura A \& Takahashi T 2011 Expression of cyclooxygenase-2 and prostaglandin receptor EP4b mRNA in the ovary of the medaka fish, Oryzias latipes: possible involvement in ovulation. Molecular and Cellular Endocrinology 332 67-77. (https://doi.org/10.1016/j.mce.2010.09.015)

Fujimori C, Ogiwara K, Hagiwara A \& Takahashi T 2012 New evidence of the involvement of prostaglandin receptor EP4b in ovulation of the medaka, Oryzias latipes. Molecular and Cellular Endocrinology 362 76-84. (https://doi.org/10.1016/j.mce.2012.05.013)

Fukada S, Sakai N, Adachi S \& Nagahama Y 1994 Steroidogenesis in the ovarian follicle of medaka (Oryzias latipes, a daily spawner) during oocyte maturation. Development, Growth and Differentiation 36 81-88. (https://doi.org/10.1111/j.1440-169X.1994.00081.x)

Garczynski MA \& Goetz, FW 1997 Molecular characterization of a ribonucleic acid transcript that is highly up-regulated at the time of ovulation in the brook trout (Salvelinus fontinalis) ovary. Biology of Reproduction 57 856-864. (https://doi.org/10.1095/biolreprod57.4.856)

Gilbert I, Robert C, Dieleman S, Blondin P \& Sirard MA 2011 Transcriptional effect of the LH surge in bovine granulosa cells during the peri-ovulation period. Reproduction 141 193-205. (https://doi.org/10.1530/REP-100381)

Goetz FW 1993 Involvement of protein kinase C in agonist-stimulated goldfish ovulation. Biology of Reproduction 48 846-850. (https://doi. org/10.1095/biolreprod48.4.846)

Grier HJ 2000 Ovarian germinal epithelium and folliculogenesis in the common snook, Centropomus undecimalis (Teleostei, Centropomidae). Journal of Morphology 243 265-281. (https://doi.org/10.1002/ (SICI)1097-4687(200003)243:3<265::AID-JMOR4>3.0.CO;2-I)

Grier HJ, Uribe MC, Parenti LR \& De la Rosa-Cruz G 2005 Fecundity, the germinal epithelium, and folliculogenesis in viviparous fishes. In Viviparous Fishes, pp 191-126. Eds MC Uribe \& HJ Grier. Homestead, FL: New Life Publications.

Grier HJ, Uribe MC \& Parenti LR 2007 Germinal epithelium, folliculogenesis, and postovulatory follicles in ovaries of rainbow trout, Oncorhynchus mykiss (Walbaum, 1792) (Teleostei, Protacanthopterygii,
Salmonfiformes). Journal of Morphology 268 293-310. (https://doi. org/10.1002/jmor.10518)

Grier HJ, Aranzábal MCU \& Patiño R 2009 The ovary, folliculogenesis, and oogenesis in teleosts. In Reproductive Biology and Phylogeny of fishes (Agnathans and Bony Fishes), pp 25-84. Ed BGM Jamieson. Enfield, $\mathrm{NH}$ : Science Publications.

Hagiwara A, Ogiwara K, Katsu Y \& Takahashi T 2014 Luteinizing hormoneinduced expression of Ptge $4 b$, a prostaglandin $E_{2}$ receptor indispensable for ovulation of the medaka Oryzias latipes, is regulated by a genomic mechanism involving nuclear protestin receptor. Biology of Reproduction 90 1-14. (https://doi.org/10.1095/biolreprod.113.115485)

Hajnik CA, Goetz FW, Hsu SY \& Sokal N 1998 Characterization of a ribonucleic acid transcript from the brook trout (Salvelinus fontinalis) ovary with structural similarities to mammalian adipsin/complement factor D and tissue kallikrein, and the effects of kallikrein-like serine proteases on follicle contraction. Biology of Reproduction 58 887-897. (https://doi.org/10.1095/biolreprod58.4.887)

Horiguchi M, Fujimori C, Ogiwara K, Moriyama A \& Takahashi T 2008 Collagen type-I $\alpha 1$ chain mRNA is expressed in the follicle cells of the medaka ovary. Zoological Science 25 937-945. (https://doi.org/10.2108/ zsj.25.937)

Hirose K 1972 The ultrastructure of the ovarian follicle of medaka, Oryzias latipes. Zeitschrift fur Zellforschung und mikroskopische Anatomie 123 316-329. (https://doi.org/10.1007/BF00335634)

Irving-Rodgers HF \& Rodgers RJ 2006 Extracellular matrix of the developing follicle. Seminars in Reproductive Medicine 24 195-203. (https://doi. org/10.1055/s-2006-948549)

Iwamatsu T 1978 Studies on oocyte maturation of the medaka, Oryzias latipes. VI. Relationship between the circadian cycle of oocyte maturation and activity of the pituitary gland. Journal of Experimental Zoology 206 355-364. (https://doi.org/10.1002/jez.1402060307)

Iwamatsu T 1980 Studies on oocyte maturation of the medaka, Oryzias latipes. VII. Role of follicular constituents in gonadotropin- and steroidinduced maturation of oocytes in vitro. Journal of Experimental Zoology 211 231-239. (https://doi.org/10.1002/jez.1402110212)

Iwamatsu T 2006 Reproduction. In The Integrated Book for the Biology of the Medaka (Japanese), pp 199-251. Okayama, Japan: University Education Press.

Iwasaki Y 1973 Histochemical detection of $\Delta^{5}$-3 $\beta$-hydroxysteroid dehydrogenase in the ovary of medaka, Oryzias latipes, during annual reproductive cycle. Bulletin of the Faculty of Fisheries Hokkaido University 23 177-184.

Kato Y, Ogiwara K, Fujimori C, Kimura A \& Takahashi T 2010 Expression and localization of collagen type IV $\alpha 1$ chain in medaka ovary. Cell and Tissue Research 340 595-605. (https://doi.org/10.1007/s00441-0100969-5)

Klangnurak W \& Tokumoto T 2017 Fine selection of up-regulated genes during ovulation by in vivo induction of oocyte maturation and ovulation in zebrafish. Zoological Letters 3, 2. (https://doi.org/10.1186/s40851017-0065-8)

Lind AK, Dahm-Kähler P, Weijdegård B, Sundfeldt K \& Brännström M 2006a Gelatinases and their tissue inhibitors during human ovulation: increased expression of tissue inhibitor of matrix metalloproteinase- 1 . Molecular Human Reproduction 12 725-736. (https://doi.org/ 10.1093/ molehr/gal086)

Lind AK, Weijdegård B, Dahm-Kähler P, Mölne J, Sundfeldt K \& Brännström M 2006b Collagens in the human ovary and their changes in the perifollicular stroma during ovulation. Acta Obstetricia Gynecologica Scandinavica 85 1476-1484. (https://doi. org/10.1080/00016340601033741)

Liu Y, Liu X, Nin L, Shi L \& Chen S 2013 Serine protease and ovarian paracrine factors in regulation of ovulation. Frontiers in Bioscience 18, 650-664. (https://doi.org/10.2741/4128)

Liu DT, Brewer MS, Chen S, Hong W \& Zhu Y 2017 Transcriptomic signatures for ovulation in vertbrates. General and Comparative Endocrinology 247 74-86. (https://doi.org/10.1016/j.ygcen.2017.01.019)

Lussier JG, Diouf MN, Levesque V, Sirois J \& Ndiaye K 2017 Gene expression profiling of upregulated mRNAs in granulosa cells of bovine ovulatory follicles following stimulation with hCG. Reproductive Biology and Endocrinology 15 88. (https://doi.org/10.1186/s12958-017-0306-x)

McCord LA, Li F, Rosewell KL, Brännström M \& Curry TE Jr 2012 Ovarian expression and regulation of the stromelysins during the perovulatory 
period in the human and the rat. Biology of Reproduction $\mathbf{8 6}$ 78. (https:// doi.org/10.1095/biolreprod.111.095588)

Migone FF, Gowan RG, Williams RM, Gorse KJ, Zipfel WR \& Quirk SM 2016 In vivo imaging reveals an essential role of vasoconstriction in rupture of the ovarian follicle at ovulation. PNAS 113 2294-2299. (https://doi.org/10.1073/pnas.1512304113)

Nagahama Y 1983 The functional morphology of teleost gonads. In Fish Physiology, vol. IX, pp 223-275. Eds WS Hoar, DJ Randall and EM Donaldson. New York: Academic Press.

Nagahama Y 1997 17 $\alpha, 20 \beta$-Dihydroxy-4-pregnen-3-one, a maturationinducing hormone in fish oocytes: mechanisms of synthesis and action. Steroids 62 190-196. (https://doi.org/10.1016/S0039-128X(96)00180-8)

Nagahama Y \& Yamashita M 2008 Regulation of oocyte maturation in fish. Development, Growth and Differentiation 50 S195-S219. (https://doi. org/10.1111/j.1440-169X.2008.01019.x)

Nagahama Y, Young G \& Adachi S 1985 Effects of actinomycin D and cycloheximide on gonadotropin-induced $17 \alpha, 20 \beta$-dihydroxy-4pregnen-3-one production by intact follicles and granulosa cells of the amago salmon, Oncorhynchus rhodurus. Development, Growth and Differentiation 27, 213-221. (https://doi.org/10.1111/j.1440169X.1985.00213.x)

Ny T, Wahlberg P \& Brändström IJM 2002 Matrix remodeling in the ovary: regulation and functional role of the plasminogen activator and matrix metalloproteinase systems. Molecular and Cellular Endocrinology 187 29-38. (https://doi.org/10.1016/S0303-7207(01)00711-0)

Ogiwara K \& Takahashi T 2016 A dual role for melatonin in medaka ovulation: ensuring prostaglandin synthesis and actin cytoskeleton rearrangement in follicle cells. Biology of Reproduction 94 64. (https:// doi.org/10.1095/biolreprod.115.1333827)

Ogiwara K \& Takahashi T 2017 Involvement of the nuclear progestin receptor in $\mathrm{LH}$-induced expression of membrane type 2-matrix metalloproteinase required for follicle rupture during ovulation in the medaka, Oryzias latipes. Molecular and Cellular Endocrinology 450 54-63. (https://doi.org/10.1016/j.mce.2017.04.016)

Ogiwara K, Takano N, Shinohara M, Murakami M \& Takahashi T 2005 Gelatinase $A$ and membrane-type matrix metalloproteinases 1 and 2 are responsible for follicle rupture during ovulation in the medaka. PNAS 102 8442-8447. (10.1073/pnas.0502423102)

Ogiwara K, Minagawa K, Takano N, Kageyama T \& Takahashi T 2012 Apparent involvement of plasmin in early-stage follicle rupture during ovulation in medaka. Biology of Reproduction 86 113. (https://doi. org/10.1095/biolreprod.111.093880)

Ogiwara K, Fujimori C, Rajapakse S \& Takahashi T 2013 Characterization of luteinizing hormone and luteinizing hormone receptor and their indispensable role in the ovulatory process of the medaka. PLOS ONE 8 e54482. (https://doi.org/10.1371/journal.pone.0054482)

Ogiwara K, Hagiwara A, Rajapakse S \& Takahashi T 2015 The role of urokinase plasminogen activator and plasminogen activator inhibitor-1 in follicle rupture during ovulation in the teleost medaka. Biology of Reproduction 92 10. (https://doi.org/10.1095/biolreprod.114.121442)

Ohnishi J, Ohnishi E, Shibuya H \& Takahashi T 2005 Functions for proteinases in the ovulatory process. Biochimica et Biophysica Acta 1751 95-109. (10.1016/j.bbapap.2005.05.002)

Onitake K \& Iwamatsu T 1986 Immunocytochemical detection of steroid hormones in the granulosa cells of the medaka, Oryzias latipes. Journal of Experimental Zoology 239 97-103. (https://doi.org/10.1002/ jez.1402390112)

Patiño R, Yoshizaki G, Bolamba D \& Thomas P. 2003 Role of arachidonic acid and protein kinase $\mathrm{C}$ during maturation-inducing hormonedependent meiotic resumption and ovulation in ovarian follicles of Atlantic croaker. Biology of Reproduction 68 516-523.

Pendergrass P \& Schroeder PC 1976 The ultrastructure of the thecal cells of the teleost, Oryzias latipes, during ovulation in vitro. Journal of Reproduction and Fertility 47 229-233. (https://doi.org/10.1530/ jrf.0.0470229)

Planas JV, Goetz FW \& Swanson P 1997 Stimulation of brook trout ovulation steroidogenesis by gonadotropins I and II is mediated by the cyclic adenosine 3',5'-monophosphate/protein kinase A pathway. Biology of Reproduction 57 647-654. (https://doi.org/10.1095/biolreprod57.3.647)

Puttabyatappa M, Jacot TA, Al-Alem LF, Rosewell KL, Duffy DM, Brännström M \& Curry TE Jr 2014 Ovarian membrane-type matrix metalloproteinases: induction of MMP14 and MMP16 during the perovulatory period in the rat, macaque, and human. Biology of Reproduction 91 34. (https://doi.org/10.1095/biolreprod.113.115717)

Puttabyatappa M, Al-Alem LF, Zakerkish F, Rosewell KL, Brännström M \& Curry TE Jr 2017 Induction of tissue factor pathway inhibitor 2 by hCG regulates periovulatory gene expression and plasmin activity. Endocrinology 158 109-120. (https://doi.org/ 10.1210/en.2016-1544)

Richards JS 2005 Ovulation: new factors that prepare the oocyte for fertilization. Molecular and Cellular Endocrinology 234 75-79. (https:// doi.org/10.1016/j.mce.2005.01.004)

Richards JS 2007 Genetics of ovulation. Seminars in Reproductive Medicine 25 235-242. (https://doi.org/10.1055/s-2007-980217)

Richards JS, Liu Z \& Shimada M 2015 Ovulation. In Knobil and Neill's Physiology of Reproduction, edn 4, pp 997-1021. Eds TM Plant \& AJ Zeleznik. Amsterdam: Academic Press.

Rodgers RJ, Irving-Rodgers HF \& Russell DL 2003 Extracellular matrix of the developing follicle. Reproduction 126 415-424. (https://doi. org/10.1530/rep.0.1260415)

Rosewell KL, Li F, Puttabyatappa M, Akin JW, Brännström M \& Curry TE Jr 2013 Ovarian expression, localization, and function of tissue inhibitor of metalloproteinase 3 (TIMP3) during the periovulatory period of the human menstrual cycle. Biology of Reproduction 89 121. (https://doi. org/ 10.1095/biolreprod.112.106989)

Rosewell KL, Al-Alem L, Zakerkish F, McCord L, Akin JW, Chaffin CL, Brännström M \& Curry TE Jr 2015 Induction of proteinases in the human perovulatory follicle of the menstrual cycle by hCG. Fertility and Sterility 103 826-833. (https://doi.org/10.1016/j.fertnstert.2014.11.017)

Sakai N, Iwamatsu T, Yamauchi K \& Nagahama Y 1987 Development of the steroidogenic capacity of medaka (Oryzias latipes) ovarian follicles during vitellogenesis and oocyte maturation. General and Comparative Endocrinology 66 333-342. (https://doi.org/10.1016/00166480(87)90242-5)

Sakai N, Iwamatsu T, Yamauchi K, Suzuki N \& Nagahama Y 1988 Influence of follicular development on steroid production in the medaka (Oryzias latipes) ovarian follicle in response to exogenous substrates. General and Comparative Endocrinology 71 516-523. (https://doi.org/10.1016/00166480(88)90282-1)

Santos HB, Sato Y, Moro L, Bazzoli N \& Rizzo E 2008 Relationship among follicular apoptosis, integrin $\beta 1$ and collagen type IV during early ovarian regression in the teleost Prochilodus argenteus after induced spawning. Cell and Tissue Research 332 159-170. (https://doi.org/10.1007/s00441007-0540-1)

Senthilkumaran B 2011 Recent advances in meiotic maturation and ovulation: comparing mammals and pisces. Frontiers in Bioscience $\mathbf{1 6}$ 1898-1914. (https://doi.org/10.2741/3829)

Sirois J, Boerboom D \& Sayasith K 2004a Prostaglandin biosynthesis and action in the ovary. In The Ovary, pp 233-247. Eds PCK Leung \& EY Adashi. San Diego: Academic Press.

Sirois J, Sayasith K, Brown KA, Stock AE, Bouchard N \& Doré M 2004 b Cyclooxygenase-2 and its role in ovulation: a 2004 account. Human Reproduction Update 10 373-385. (https://doi.org/10.1093/humupd/ dmh032)

Smith M.F, Riche WA, Bakke LJ, Dow MP \& Smith GW 2002 Ovarian tissue remodeling: role of matrix metalloproteinases and their inhibitors. Molecular and Cellular Endocrinology 191 45-56. (https://doi. org/10.1016/S0303-7207(02)00054-0)

Stouffer RL, Xu F \& Duffy DM 2007 Molecular control of ovulation and luteinization in the primate follicle. Frontiers in Bioscience 12 297-307. (https://doi.org/10.2741/2065)

Sugimoto Y, Inazumi T \& Tsuchiya S 2015 Roles of prostaglandin receptors in female reproduction. Journal of Biochemistry 157 73-80. (https://doi. org/10.1093/jb/mvu081)

Takahashi A, Kanda S, Abe T \& Oka Y 2016 Evolution of the hypothalamicpituitary-gonadal axis regulation in vertebrates revealed by knockout medaka. Endocrinology 157 3994-4002. (https://doi.org/10.1210/ en.2016-1356)

Takahashi T, Hagiwara A \& Ogiwara K 2018 Prostaglandins in teleost ovulation: a review of the roles with a view to comparison with prostaglandins in mammalian ovulation. Molecular and Cellular Endocrinology $\mathbf{4 6 1} \quad 236-247 . \quad$ (https://doi.org/10.1016/j. mce.2017.09.019)

Tang H, Liu Y, Li J, Yin Y, Li G, Chen Y, Li S, Zhang Y, Lin H, Liu X et al. 2016 Gene knockout of nuclear progesterone receptor provides insights 
into the regulation of ovulation by LH signaling in zebrafish. Scientific Reports 6 28545. (https://doi.org/10.1038/srep28545)

Thomas P 2012 Rapid steroid hormone actions initiated at the cell surface and the receptors that mediate them with an emphasis on recent progress in fish models. General and Comparative Endocrinology 175 367-383. (https://doi.org/10.1016/j,ygcen.2011.11.032)

Thomé R, dos Santos HB, Sato Y, Rizzo E \& Bazzoli N 2010 Distribution of laminin $\beta 2$, collagen type IV, fibronectin and MMP-9 in ovaries of the teleost fish. Journal of Molecular Histology 41 215-224. (https://doi. org/10.1007/s10735-010-9281-7)

Tokumoto M, Nagahama Y, Thomas P \& Tokumoto T 2006 Cloning and identification of a membrane progestin receptor in goldfish ovaries and evidence it is an intermediary in oocyte meiotic maturation. General and Comparative Endocrinology 145 101-108. (https://doi.org/10.1016/j. ygcen.2005.07.002)

Tsafriri A \& Dekel N 1994 Molecular mechanisms in ovulation. In Molecular Biology of the Female Reproductive System, pp 207-258. Ed JK Findlay. San Diego: Academic Press.

Tsafriri A \& Reich R 1999 Molecular aspects of mammalian ovulation. Experimental and Clinical Endocrinology and Diabetes 107 1-11. (https://doi.org/10.1055/s-0029-1212066)

Wallace RA \& Selman K 1981 Cellular and dynamic aspects of oocyte growth in teleosts. American Zoologist 21 325-343. (https://doi. org/10.1093/icb/21.2.325)

Yamamoto M 1963 Electron microscopy of fish development. II. Oocytefollicle cell relationship and formation of chorion in Oryzias latipes. Journal of the Faculty of Science University of Tokyo Section IV $\mathbf{1 0}$ 123-127.
Zhang Z, Lau SW, Zhang L \& Ge W 2015 Disruption of zebrafish folliclestimulating hormone receptor (fshr) but not luteinizing hormone receptor (lhcgr) gene by TALEN leads to failed follicle activation in females followed by sexual reversal to males. Endocrinology 156 3747-3762. (https://doi.org/ 10.1210/en.2015-1039)

Zhu Y, Rice CD, Pang YF, Pace M \& Thomas P 2003 Cloning, expression, and characterization of a membrane progestin receptor and evidence it is an intermediary in meiotic maturation of fish oocytes. PNAS $\mathbf{1 0 0}$ 2231-2236. (https://doi.org/10.1073/pnas.0336132100)

Zhu Y, Hanna RN, Schaaf MJM, Spaink HP \& Thomas P 2008 Candidates for membrane progestin receptors in vertebrates- past approaches and future challenges. Comparative Biochemistry and Physiology - Part C Toxicology and Pharmacology 148 381-389. (https://doi.org/10.1016/j. cbpc.2008.05.019)

Zhu Y, Liu D, Shaner ZC, Chen S, Hong W \& Stellwag EJ 2015 Nuclear progestin receptor (pgr) knockouts in zebrafish demonstrate role for pgr in ovulation but not in rapid nongenomic steroid mediated meiosis resumption. Frontiers in Endocrinology 6 37. (https://doi.org/ 10.3389/ fendo.2015.00037)

Received 16 May 2018

First decision 26 June 2018

Revised manuscript received 12 October 2018

Accepted 25 October 2018 